\title{
Animal Law: Human Duties or Animal Rights?
}

\author{
Torben Spaak*
}

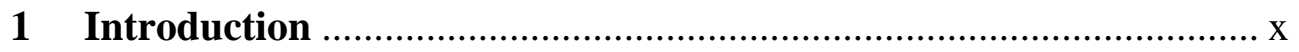

2 The Moral Status of Animals ..........................................................

3 Conceptual Questions....................................................................

4 The Functions of the Concept of a Legal Right .............................. $\mathrm{x}$

5 First- and Second-Order Legal Statements................................... $\mathrm{x}$

6 Hohfeld's Fundamental Concepts ................................................ $\mathrm{x}$

7 The Will-Theory and the Interest-Theory ...................................... $\mathrm{x}$

8 The Will-Theory and the Interest-Theory:

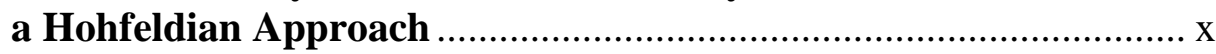

9 The Will-Theory and the Interest-Theory: Pros and Cons ............. X

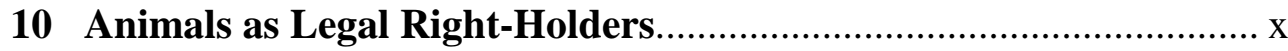

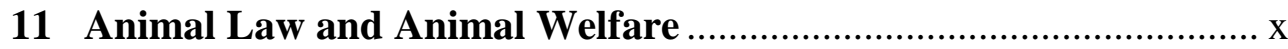




\section{Introduction}

In my view, the moral case for giving animals legal protection is strong. This is so whether or not we think of animals as having moral rights, such as a right to be cared for, or at least a right not to be harmed, because even if animals do not have moral rights, humans have moral duties toward animals, such as a general duty not to harm animals, say, by performing experiments on them, or raising them for food, or having them perform tricks to amuse tourists. The question I wish to consider in this article, however, is not what moral rights animals have, or even what our moral duties to animals are, but whether we have reason to think of animal law not only as imposing legal duties on humans, but also as conferring legal rights on animals. This is not a moral question, but a question about how to conceptualize legal positions, and the arguments in favor of or against competing conceptualizations should be of a theoretical nature. Although the focus of legal scholars is only rarely on conceptual questions, such questions are nevertheless important. For having a reasonably thought-out view of the structure, content, and applicability of relevant legal concepts will be conducive to clear legal thinking, and clear legal thinking in turn is conducive not only to correct legal thinking, but also to efficiency.

I shall argue (A) that while there are good moral reasons to impose legal duties on humans regarding the treatment of animals, there are good theoretical reasons not to think of animals as legal right-holders, because doing so would either be pointless, on the interest-theory analysis, or else incoherent, on the willtheory analysis. On route to this conclusion, I shall also argue (B) that in the field of law, the method of explication is in many cases, including the elucidation of the concept of a legal right, preferable to conceptual analysis, strictly conceived; (C) that we should think of legal rights as complexes of Hohfeld-elements (claims, liberties, powers, immunities) and distinguish accordingly between claim-rights, liberty-rights, power-rights, and immunity-rights; (D) that when discussing animal rights we should focus on claim-rights; and, finally, (E) that an explication of the concept of a legal right along the lines of the will-theory of legal rights is preferable to an explication along the lines of the interest-theory.

I begin with a brief consideration of the questions of the moral status of animals (Section 2), conceptual questions in law (Section 3), the function of the concept of a legal right (Section 4), and the analysis of legal statements (Section 5). I then introduce Hohfeld's fundamental legal concepts (Section 6) and proceed to consider, in light of Hohfeld's analysis, the opposition between willtheories and interest-theories of legal rights (Section 7-9). Having done that, I turn to the question of whether we should conceive of animal protection law partly in terms of animal rights or solely in terms of human duties (Section 10). The article concludes with some brief thoughts on the place of conceptual analysis in animal law (Section 11).

* Torben Spaak, LL.D., Professor of Jurisprudence, Faculty of Law, Stockholm University.

Email: Torben.Spaak@juridicum.su.se. I would like to thank the participants in the advanced seminar in practical philosophy in the Department of Philosophy, Uppsala University, as well as William Bülow, and Åke Frändberg for helpful comments on the article. Thanks also to Visa Kurki, who in his capacity as scientific coordinator of the volume offered a number of helpful comments. I would also like to thank Robert Carroll for checking my English. As always, the responsibility for any remaining errors and imperfections remains solely with the author. 


\section{The Moral Status of Animals}

I said above that I believe the moral case for giving animals legal protection is strong. ${ }^{1}$ I believe, more specifically, that animals have moral status at least in the sense that they exist for their own sake, not for the sake of humans, and possibly also in the stronger sense that we should give equal consideration to animal interests and humans interests, at least as regards the interest in life and in avoiding pain. ${ }^{2}$ This means, among other things, that when I maintain that it is morally wrong to harm animals, I do not mean that this is so because harming animals would somehow harm human interests, although this may well be the case, but because it would harm the interests of animals, and because interests of the latter type exist independently of the former. However, while these ideas are important, they do not establish that animals should or may be seen as having moral rights. To be sure, some people who maintain that animals have moral rights may mean to say only that animals have moral status in the sense explained, and if this is all they mean, I agree. But when I speak of (moral or legal) rights, I mean something more, and I will explain in the following what that is.

\section{Conceptual Questions}

Clearly, the answer to the question of whether we have reason to think of animals as legal right-holders depends to a considerable extent on what we take a legal right to be, and I shall therefore discuss this conceptual question at some length. Let me explain what I mean by a 'conceptual question.' Generally speaking, it is a good idea to distinguish as clearly as one can between normative, empirical, and conceptual questions. ${ }^{3}$ Normative questions are questions about what one ought to do, or may or may not do, or about what one has a right to do or receive. ${ }^{4}$ Examples of normative questions include 'May we raise animals for food?', 'Do we have an obligation to obey the law?', 'How should I live my life?', or 'Where should I go on my summer vacation?' As these examples make clear, not all normative questions are moral or legal questions.

Empirical questions are questions that can be answered by observation, by using our five senses, perhaps with the help of instruments, such as telescopes or microscopes. Examples include 'How many animal hospitals are there in

1 On this, see, e.g., Peter Singer, Animal Liberation (Updated edn, HarperCollins, 2009). (Originally published 1975.); Tom Regan, The Case for Animal Rights (2nd edn, University of California Press, 2004). (Originally published 1983.)

2 See David DeGrazia, Animal Rights. A Very Short Introduction (Oxford University Press, 2002) 12-38. This means, of course, that I am focusing on 'higher' animals in this article, not insects or snails, and the like. I am by no means sure where exactly the line should be drawn, however.

3 See, e.g., Robert Alexy, A Theory of Legal Argumentation (Oxford University Press, 1989) 15-6. (Originally published 1978 by Suhrkamp Verlag under the title Theorie der juristischen Argumentation.)

4 We may also include evaluative questions - questions about what is good or bad - in the category of normative questions, though one might for some purposes wish to treat evaluative questions separately. On this topic, see Georg Henrik von Wright, The Varieties of Goodness (Routledge \& Kegan Paul, 1963) 6-7. 
Stockholm?', 'What is the current unemployment rate in Canada?', and 'How far is it to the Moon?'. Empirical questions are, of course, factual questions, but not all factual questions are empirical questions. Logical and mathematical questions, for example, are factual, but not empirical, because our knowledge of the answers to these questions does not depend on observation.

Conceptual questions, finally, are questions about the structure and content of concepts, such as the concept of law, the concept of a legal right, the concept of harm, or the concept of knowledge, to take just a few examples. Although experts disagree about what, exactly, a concept is, we may think of concepts, roughly, as meanings (senses) of words or expressions (terms). ${ }^{5}$ On this analysis, to ask for the content of the concept of a legal right is, roughly, to ask for the meaning of the word(s) 'legal right. ${ }^{\prime 6}$ Moreover, a given word or expression may express the same concept as another word or expression in the same or in a different language; if instead it is ambiguous, if it has more than one sense, then it expresses more than one concept. Note that, on this analysis, the sense, or intension, of a word or an expression determines its reference or extension, that is, the class of entities or properties to which the word applies, in our case the class of legal rights. ${ }^{7}$ In any case, for our purposes, the central conceptual question is, 'What is the structure and content of the concept of a legal right?', or, more colloquially, 'What is a legal right?'

As regards the enterprise of analyzing or clarifying a given concept, we may distinguish between analyzing a concept in the strict sense of attempting to establish an analytically true equivalence between analysandum (that which is to be analyzed) and analysans (that which does the analyzing), and explicating a concept in the sense of attempting to make sharper the contours of a somewhat unclear, or pre-theoretical, concept, in order to make the concept (more) suitable for a certain purpose. ${ }^{8}$ Whereas an analysis will be true or false (or correct or incorrect), an explication will rather be more or less adequate in relation to its purpose; and the criteria of adequacy for such an explication are not moral, but theoretical, namely, that the explicated concept (the explicatum) should be (i) similar to the original concept (the explicandum), (ii) precise, (iii), fruitful, and (iv) simple. Note that the question of how to weigh these different criteria against one another is to be answered on pragmatic grounds, typically in light of the purpose of the explication.

To explicate a concept, then, is not to construct a new concept from scratch, but to mold an existing concept in light of an epistemic, not a moral, purpose, and this means that explications are normative only in a very limited way. As Georg Henrik von Wright puts it,

5 For more on this topic, see Eric Margolis and Stephen Laurence, 'Concepts' in Edward N. Zalta (ed), The Stanford Encyclopedia of Philosophy (Summer 2019 Edition), URL = $<$ https://plato.stanford.edu/archives/sum2019/entries/concepts/>.

6 On this, see Torben Spaak, 'Schauer’s Anti-Essentialism’ (2016) 29 Ratio Juris 182, 192-3.

7 Of course, this does not apply to natural-kind words, such as 'water,' 'gold,' 'tiger,' etc., since these words have meaning (in a limited way) by virtue of being causally related to the corresponding natural kind. On natural kinds and natural-kind words in general, see, e.g., Mark Platts, Ways of Meaning (2nd edn, The MIT Press, 1997) 264-92; A. C. Grayling, An Introduction to Philosophical Logic (3rd edn, Blackwell, 1997) 195-202.

8 On this, see Spaak, 'Schauer’s Anti-Essentialism' (n 6) 187-94, 205-8. 
Philosophic reflexion on the grounds for calling a thing ' $\mathrm{x}$ ' is challenged in situations, when the grounds have not been fixed, when there is no settled opinion as to what the grounds are. The concept still remains to be moulded and therewith its logical connexions with other concepts to be established. The words and expressions, the use of which bewilder the philosopher, are so to speak in search of a meaning. ${ }^{9}$

Given that both legal professionals and laymen speak of legal (and moral) rights in a rather indeterminate way, ${ }^{10}$ and that it would therefore be futile to aim at an analysis that corresponds, even roughly, to legal usage, not to mention ordinary usage, the method of explication is likely to be the most fruitful method for one who wishes to elucidate, or clarify, the concept of a legal right. Accordingly, we shall not be concerned with the question of what a legal right is, but with the question of what it should be, given (i) a certain core idea (or ideas) in the pre-theoretical concept of a legal right, (ii) the purpose of the explication, and (iii) the above-mentioned criteria. As a result, a given explication of the concept of a legal right might cover some entities that we have pre-theoretically not called rights, or might not cover some entities that we have pre-theoretically called rights, or both.

I shall assume in what follows, in keeping with the said, that to have a legal right is to be legally protected by the imposition of normative constraints on other persons in such a way that one is typically able to decide, according to one's own lights, how one is to act (or not act), or how another person is to act (or not act); and I shall say that the purpose of my explication is to mold a concept of a legal right that will be useful in legal thinking in general. One could, of course, aim to explicate a concept of a legal right not for legal thinking in general, but for legal thinking in the field of animal law, or for some even more specific purpose. The more specific the purpose of an explication, however, the more restricted the scope of application of the explication will be; and if we allow that a legal right may be one thing in the field of animal law, another thing in family law, and yet a third thing in tax law, say, we will make it more difficult to take a general view of the law.

We see, then, that questions concerning the structure and content of the concept of a legal right are different from questions about what legal rights we do have, or ought to have. To be sure, the distinction between conceptual analysis, on the one hand, and empirical or normative questions, on the other, is not air-tight. The reasons being that any analysis of the concept of a legal right must be consistent with our (pre-analytical) view of what legal rights exist, if it is to be considered an analysis of the concept of a legal right in use and not a proposal to introduce a different concept, and that normative or evaluative considerations may in some cases intrude on empirical considerations when the question is what legal rights there are. Nevertheless, there is an important difference between analyzing, or explicating, a legal concept, on the one hand, and taking a moral stand for or against a certain understanding of a legal concept, on the other.

9 von Wright, Goodness (n 4) 5.

10 On the proliferation and resultant indeterminacy of rights-language, see L. W. Sumner, The Moral Foundation of Rights (Oxford University Press, 1987) 2-14. 


\section{The Functions of the Concept of a Legal Right}

If an explication of the concept of a legal right is to be useful in legal thinking, one who intends to explicate this concept needs to consider the question of what function, or functions, this concept plays, or is supposed to play, in legal thinking. This question is not so easy to answer, however. I would say that, generally speaking, the function of rights in law and elsewhere is to protect the right-holder by imposing normative constraints on others, and that rights can fulfill this function because they have peremptory normative force that typically trumps competing normative considerations, whether based on private or public interest, or both. ${ }^{11}$ On this analysis, to have a right to do or get something is to have a very forceful normative reason on one's side, a reason that, normatively speaking, trumps most competing reasons.

So far so good. Let us now proceed to distinguish between (i) the view that the concept of a legal right is internally complex and that there is a "logic of rights" in the sense that we can, if we have the necessary legal skills, spell out the specific normative conclusions - say, that the right-holder has a legal liberty to do and to abstain from doing $X$, or a legal claim that others not interfere with his doing or abstaining from doing $Y$ - that are thus implicit in the concept of a legal right, and (ii) the view that the concept is internally simple and consists of either a single legal claim, a single legal liberty, a single legal power, or a single legal immunity, as the case may be, which entails a corresponding duty, noclaim, liability, or disability. ${ }^{12}$ Note that on both these views, the concept of a legal right occurs typically in legal premises, and that the difference between the two views is that the former, but not the latter, view assumes that the complexity of the concept of a right necessitates a logic of rights, in order to spell out specific normative conclusions (claims, liberties, etc.); in the latter case, no logic of rights is needed, because the normative conclusion is obvious. However, to these two views about the function of the concept of a legal right, we should add (iii) the view proposed by the early Hart, namely, that the concept of a legal right typically occurs in legal conclusions. ${ }^{13}$ On this view, we use the concept of a legal right to state or report the content of the law in a conspicuous and facile way. As should be clear, (iii) is the contradictory opposite of (i).

I am inclined to think that the concept of a legal right often, but not always, occurs in legal conclusions, and that it is therefore not very useful in ordinary legal problem-solving. As far as I can see, the closest we come to something

11 My characterization of the function of rights is inspired by Sumner, Moral Foundation (n 10) 17.

12 On this, see N. E. Simmonds, Central Issues in Jurisprudence. Justice, Law and Rights (4th edn, Sweet \& Maxwell, 2002) 268-71. As we shall see (in Section 6), Simmonds proposes that Hohfeld was a proponent of (ii). See Wesley Newcomb Hohfeld, Fundamental Legal Conceptions as Applied in Judicial Reasoning. With an Introduction by Nigel Simmonds. (Eds) David Campbell and Philip Thomas (Ashgate, 2001) 12-3. (Originally published as two articles in the Yale Law Journal 1913 and 1917.)

13 H. L. A. Hart, 'Definition and Theory in Jurisprudence' in H. L. A. Hart, Essays in Jurisprudence and Philosophy (Clarendon Press, 1983) 21, 35. (Originally published in Law Quarterly Review.) Hart does not, however, mention this idea in his later, influential analysis of the concept of a legal right. See H. L. A. Hart, 'Bentham on Legal Rights' in A. W. B. Simpson (ed), Oxford Essays in Jurisprudence (Second Series) (Clarendon Press, 1973) 171201. 
resembling a logic of rights is when judges, attorneys, or legal scholars, argue from the premise that a person has a human or a constitutional right, or, perhaps, a right of ownership, to a specific normative conclusion, say, that the right-holder is at liberty to leave the country, or to refuse to join a union, or that he may sell or make use of his piece of land as he sees fit. ${ }^{14} \mathrm{I}$ am less sure that the concept otherwise plays an important role in legal problem-solving in either private law or public law, because it seems to me that one is here rarely assuming legal rights as premises, but is rather arriving at them as conclusions, as Hart proposes, and such conclusions are not very important when seen from the point of view of legal problem-solving; what is important are the specific conclusions about legal claims, liberties, duties, powers, etc.

\section{First- and Second-Order Legal Statements}

Having said that we are aiming at a concept of a legal right that is useful in legal thinking in general, and that the concept of a legal right typically, but not exclusively, occurs in legal conclusions, we need to consider a distinction between two types of legal statements - such as "Smith has a duty to pay income tax" or "All animals have a right not to be harmed by humans" - namely, firstorder legal statements, which are normative, and second-order legal statements, which are descriptive. ${ }^{15}$ And if we do, we should also consider the following question: Does the concept of a legal right typically occur in first-order statements, or in second-order statements, or in both? Alf Ross, for example, appears to have intended his syntax-based account of the concept of a legal right - according to which the function of a legal right is to connect a disjunction of legal grounds with a conjunction of legal consequences - to apply only to second-order legal statements. ${ }^{16}$

As I see it, both legal premises and legal conclusions can occur in both firstorder and second-order legal statements, and a competent analysis of the concept of a legal right therefore needs to cover the occurrence of the concept in both first- and second-order legal statements. However, if and insofar as we aim to account for the concept of a legal right as it occurs in first-order legal statements, we need to consider the meta-ethical analysis of such statements. There may be a problem here, however, namely, that an otherwise attractive type of metaethical theory of legal and moral statements, which is called non-cognitivism, has it that normative statements are not reports about anything, but are instead

14 On this, see Simmonds, Central Issues (n 12) 268-9. As Simmonds points out, one may well wonder whether legal reasoning from rights to more specific normative conclusions is best described as a logic of rights or as a rather free policy argumentation that only pretends to be a logical development of the content of the relevant right.

15 I discuss this distinction elsewhere. See, e.g., Torben Spaak, A Critical Appraisal of Karl Olivecrona's Legal Philosophy (Springer, 2014) 97-100. I shall not here discuss so-called detached legal statements, that is, legal statements made from a normative point of view that the speaker does not accept. On detached statements, see Joseph Raz, The Authority of Law ( $2^{\text {nd }}$ edn, Oxford University Press, 2009) 140-3. I discuss detached statements in Torben Spaak, 'Legal Positivism, Conventionalism, and the Normativity of Law' (2018) 9 Jurisprudence 319, 331-3.

16 Alf Ross, ‘Tü-Tü’ (1957) 70 Harvard Law Review 812-25. For more on this topic, see Torben Spaak, 'Alf Ross on the Concept of a Legal Right' (2014) 27 Ratio Juris 461, 470-1. 
prescriptions, or expressions of the speaker's feelings, attitudes, or preferences; and thus conceived, normative statements are neither true nor false, and normative words, such as 'right' and 'duty' (and value words such as 'good' and 'bad') that occur in such statements do not have cognitive (or representational) meaning, at least not in the same straightforward way as they do when they occur in second-order normative statements; ${ }^{17}$ and this in turn appears to mean that when such a word occurs in first-order statements, the relevant concept has no content that the analyst could clarify or elucidate. ${ }^{18}$ I find this implication, especially when combined with the closely related Frege-Geach problem, ${ }^{19}$ to be so bothersome, that I feel compelled to assume that we can understand firstorder legal statements along the lines of meta-ethical relativism, or fictionalism, or error-theory.

\section{Hohfeld's Fundamental Concepts}

Like many others, ${ }^{20} \mathrm{I}$ believe the best way to conceive of legal rights is to think of them as complexes of Hohfeld elements. In two articles published in the beginning of the twentieth century, Wesley Newcomb Hohfeld introduced eight fundamental legal conceptions, as he called them, saying they were sui generis and "the basic conceptions of the law - the legal elements that enter into all types

17 Simon Blackburn's quasi-realism, for example, can be seen as an attempt to account on the basis of expressivism for the cognitive meaning of normative and evaluative words when they occur in first-order moral (or legal) statements. See Simon Blackburn, Spreading the Word (Oxford University Press, 1984) chap. 6. The idea is that we should anchor the semantics of normative or evaluative predicates, such as "has a right" or "is good," in the attitudes of the speaker, and that therefore the important question is not what the world is like, but under what conditions it is semantically appropriate to say that a person has a right, or that an action is good or bad, etc. Of special relevance here is what Alexander Miller refers to as ambitious, as distinguished from moderate, quasi-realism, according to which there really are moral facts and moral truths, though we can account for them (only) on an expressivist basis. See Alexander Miller, An Introduction to Contemporary Metaethics (Oxford, Polity Press, 2003) 278. Blackburn's very interesting account is rather complicated, however, and I shall not consider it any further here. I have, however, expressed doubts about it in Torben Spaak, 'Legal Realism and Legal Reasoning: A Quasi-Realist Approach' in Christoph Bezemik, Michael Potacs, and Alexander Somek (eds), Vienna Lectures on Legal Philosophy (Hart Publishing, 2020) 113-139.

18 Moral cognitivists hold that normative statements can be true or false in a relativistic sense (meta-ethical relativism), true or false in a non-relativistic sense (realism, non-relativist constructivism, fictionalism), or only false (error theory), and that value words and normative words have cognitive meaning when they occur in such statements; and this means that an analysis of the concept of a legal right in first-order statements on the basis of a cognitivist metaethics will avoid the above-mentioned difficulty. On these metaethical theories, see, e.g., Mark van Roojen, Metaethics. A Contemporary Introduction (Routledge, 2015).

19 P. T. Geach, 'Assertion,' (1965) 74 The Philosophical Review 449-465.

20 See, e.g., Hart, 'Legal Rights' (n 13); Carl Wellman, 'Legal Rights’ in Stig Strömholm (ed) Uppsalaskolan - och efteråt. Rättsfilosofiskt symposium, Uppsala 23-26 maj 1977 (Almqvist \& Wiksell, 1978) 213-221; Matthew H. Kramer, 'Rights Without Trimmings' in Matthew H. Kramer, N.E. Simmonds, and Hillel Steiner (eds), A Debate over Rights (Oxford University Press, 1998) 7-111; Hillel Steiner, 'Working Rights' in A Debate over Rights, 233-301; Sumner, Moral Foundation (n 10). 
of jural interests.” ${ }^{21}$ As he saw it, ${ }^{22}$ our tendency to think of complex legal problems in terms of rights and duties is a hindrance to clear thinking. What we need is a more fine-tuned conceptual apparatus, namely, one that includes the above-mentioned fundamental legal conceptions. I agree with Hohfeld. As I see it, these concepts set the conceptual framework for our thinking about legal positions, in the sense that one can describe any type of legal position if, and only if, one has access to them. And if the concepts are sufficient to describe any type of legal position, we can use them to analyze complex legal concepts such as 'right of ownership', 'human right,' 'jurisdiction', 'legislation,' 'juristic person,' 'citizenship', 'invalidity', 'locus standi', 'power of attorney', and more, that is, we can use them to break such complex concepts down into their constituent parts and so clarify them. The following schema makes clear the logical relations between the eight concepts:

fig. 1.
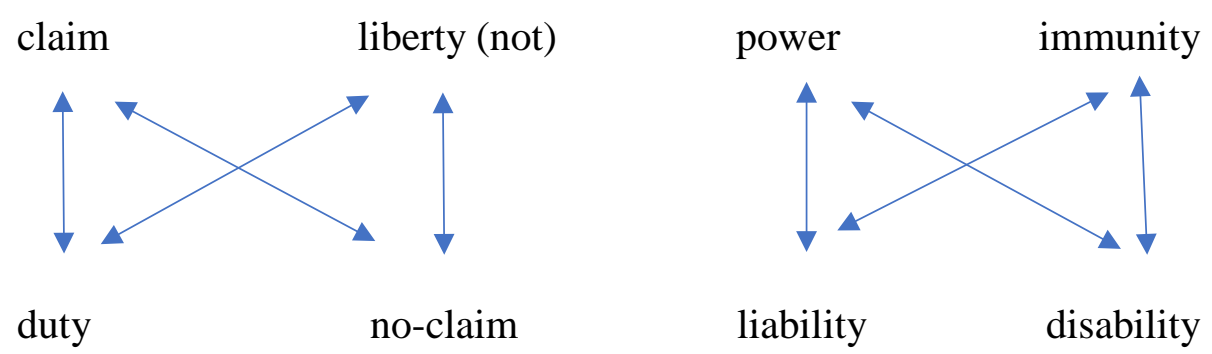

Note the following points. First, the relevant legal relations hold between precisely two persons, $A$ and $B$, and this means that we need to specify against whom the holder of a claim, duty, liberty, etc., has this claim, duty, liberty, etc. For example, the criminal law imposes on all of us a legal duty not to assault any other person. This means, on Hohfeld's analysis, that each of us has a separate legal duty not to assault Lady Gaga, say, so that I have such a duty, you have such a duty, my neighbor has such a duty, etc., and that Lady Gaga in turn has separate legal claims against each of us, that we do not assault her, that is, one claim against me, another claim against you, yet another against my neighbor, etc. ${ }^{23}$

Second, the vertical arrows indicate that the concepts in question are correlates (or correlatives), so that $A$ has a claim vis-à-vis $B$ that $B$ do (or not do) $X$ if, and only if, $B$ has a duty vis-à-vis $A$ to do (or not do) $X$; that $A$ has a liberty

21 Hohfeld, Fundamental Legal Conceptions (n 12) 27.

22 ibid. 11.

23 Hohfeld is thus treating all duties as relational duties. One may, however, wonder precisely how one is to determine whether $A$ 's duty to do $X$ is owed to a specific person, $B$, or is instead non-relational. Of course, many private law legal duties - such as contractual duties and most tort duties - are clearly owed to a specific person. But what about public law duties, such as our duty to pay income tax, or to drive carefully? This question is important in the present context, for if we don't know who is owed the duty, we don't know who, if anyone, is the right-holder. The problem concerns not only duties, of course, but if we can clarify who is owed the duty, we can also determine who has a claim, a liberty, or a no-claim against whom. I shall assume in what follows that $A$ owes a duty to $B$ if, and only if, $A$ 's fulfillment of the duty either directly benefits $B$, or is intended to benefit $B$. On this topic, see Sumner, Moral Foundation (n 10) 39-44. 
vis-à-vis $B$ to do (or not do) $X$ if, and only if, $B$ has a no-claim (= no claim) visà-vis $A$ that $A$ not do (or do) $\mathrm{X}$; that $A$ has a power vis-à-vis $B$ to change a legal position, $L P$, if, and only if, $B$ has a liability vis-à-vis $A$ as regards $A$ 's change of $L P$; and that $A$ has an immunity vis-à-vis $B$ as regards $B$ 's change of $L P$ if, and only if, $B$ has a disability (= no power) vis-à-vis $A$ to change LP.

Third, the diagonal arrows indicate that the concepts in questions are (contradictory) opposites, so that $A$ has a claim vis-à-vis $B$ that $B$ do (or not do) $X$, or $A$ has a no-claim vis-à-vis $B$ that $B$ do (or not do) $X$, but not both; that $A$ has a liberty vis-à-vis $B$ to do (or not do) $X$, or $A$ has a duty vis-à-vis $B$ not to do (or do) $X$, but not both; that $A$ has a power vis-à-vis $B$ to change $L P$, or $A$ has a disability vis-à-vis $B$ to change $L P$, but not both; and that $A$ has an immunity visà-vis $B$ with respect to $B$ 's change of $L P$, or $A$ has a liability vis-à-vis $B$ with respect to $B$ 's change of $L P$, but not both.

The circumstance that the concepts are contradictory opposites explains the negation of the action-theme, $X$, in the schema as regards the relations between liberty and duty, and between liberty and no-claim. As we saw, if $A$ has a liberty vis-à-vis $B$ to do (or not do) $X$, then $A$ has no duty vis-à-vis $B$ not to do (or do) $X$, and $B$ has a corresponding no-claim vis-à-vis $A$ that $A$ do not do (or do) $X$. This is clear from the so-called square of opposition (see fig. 2), (Op stands for 'it is obligatory to do $p$,' $O-p$ stands for 'it is obligatory to do not- $p$,' $P p$ stands for 'it is permitted to do $p$ ', $P-p$ stands for 'it is permitted to do not- $p$ ):

fig. 2.

(1)

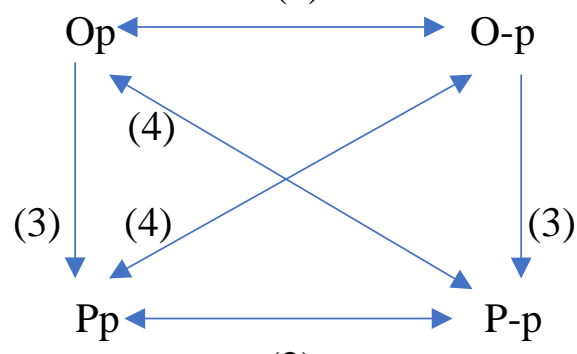

(2)

Here (1) indicates that $O p$ and $O-p$ are contrary opposites, (2) indicates that $P p$ and $P-p$ are sub-contrary opposites, (3) indicates that $O p$ entails $P p$, but not vice versa, and that $O-p$ entails $P$ - $p$, but not vice versa, and (4) indicates that $O p$ $\& P-p$ and $O-p \& P p$ are contradictory opposites. We see, then, that two contraries can both be false, but cannot both be true, that two sub-contraries can both be true, but cannot both be false, and that contradictory opposites are such that if one is true (false), the other must be false (true) ${ }^{24}$ Thus if Smith is obligated to care for his dog (Op), Smith is permitted to care for his dog (Pp), and if Jones is obligated not to harm his cat $(\mathrm{O}-\mathrm{q})$, Jones is permitted not to harm his cat (P-q); and if Smith is obligated to care for his dog (Op), Smith is not, and cannot be, permitted to not care for his dog (-P-p), and if Jones is obligated not to harm his cat $(\mathrm{O}-\mathrm{q})$, Jones is not, and cannot be, permitted to harm his cat ($\mathrm{Pq})$. Note that this is a matter of norm-logic, not a description of any legal

24 For more on this, see Pablo E. Navarro and Jorge L. Rodriguez, Deontic Logic and Legal Systems (Cambridge University Press, 2014) 17-21. I have borrowed fig. 2 from this book. 
system. Although contradictions are logically unacceptable, they may sometimes be found in a legal system, and this is the reason why most, probably all, legal orders recognize the so-called conflict-solving maxims, lex superior, lex posterior, and lex specialis.

Fourth, to understand the schema, we need of course to grasp the import of the various concepts. Hohfeld does not, however, define the concepts in an explicit way, but is content to clarify their content by relating them to one another and giving examples. ${ }^{25}$ But if we distinguish between the left, static square, which is made up of the concepts claim, duty, liberty, and no-claim, and the right, dynamic square, which is made up of the concepts power, liability, immunity, and disability, we see that the concepts are interdefinable within the respective square. ${ }^{26}$ Thus, if we can find a secure starting point, we can clarify the import of the various concepts. And, as I see it, the concepts of duty and power are the natural points of departure when explaining the import of the concepts in the respective square. We might indeed say that imposing a duty and conferring a power are, pragmatically, but not logically, speaking, the two fundamental modes of legal regulation. ${ }^{27}$

If in keeping with this we allow ourselves to assume that having a legal duty to do $X$ is to be required by a legal norm to do $X,{ }^{28}$ and that having legal power to change $L P$ is to have been given by a legal norm the possibility of changing $L P$ by performing an act-in-the-law, ${ }^{29}$ we can make progress. We see, then, that $A$ 's claim vis-à-vis $B$ that $B$ do $X$ can be analyzed in terms of $B$ 's duty vis-à-vis $A$ to do $X$; that $A$ 's no-claim vis-à-vis $B$ that $B$ do $X$ can be analyzed in terms of $B$ 's liberty not to do $X$, which in turn is equivalent to the absence of a duty on $B$ 's part to do $X$; and, finally, that $A$ 's liberty vis-à-vis $B$ to do $X$ can be analyzed in terms of the absence of a duty on the part of $A$ vis-à-vis $B$ not to do $X$. We also see that $B$ 's liability vis-à-vis $A$ to have $L P$ changed by $A$ can be analyzed in terms of $A$ 's power vis-à-vis $B$ to change $L P$; that $B$ 's immunity vis-à-vis $A$ as regards $A$ 's changing $L P$ can be analyzed in terms of the disability on the part of $A$ vis-à-vis $B$ to change $L P$, which is equivalent to the absence of a power on the

25 Hohfeld believed that explicit definitions of these concepts will always be unsatisfactory, because he held that the concepts are sui generis. Hohfeld, Fundamental Legal Conceptions (n 12) 12.

26 I speak of a static and a dynamic square, respectively, because the concepts in the dynamic square, but not the concepts in the static square, concern the creation, modification, or extinguishing of legal positions. We might also say that the concepts in the static square typically, but not exclusively, concern the behavior of (physical and juristic) persons, whereas the concepts in the dynamic square concern not the behavior of persons, but their legal positions. On this, see Kramer, Rights Without Trimmings (n 20) 20; Sumner, Moral Foundation (n 10) 27-31. Note that if the concepts can be analyzed in terms of each other, they cannot all be basic, or primitive, as Hohfeld appears to have believed.

27 Sumner, Moral Foundation (n 10) 18-31.

28 This assumption reflects a legal positivist stance. For to say that having a legal duty to do $X$ is to be required by a legal norm to do $X$, without adding anything about moral constraints on what counts as a legal norm, is to say that a legal duty is a legal duty whatever its moral force may turn out to be.

29 I mean by an 'act-in-the-law' an act that depends for its legal effect on having been performed with the (actual or imputed) intention to bring about the said effect. On this, see Torben Spaak, 'Explicating the Concept of Legal Competence' in Jaap C. Hage and Dietmar von der Pfordten (eds), Concepts in Law (Springer, 2009) 67, 76-7. 
part of $A$ vis-à-vis $B$ to change $L P$; and that $A$ 's disability vis-à-vis $B$ to change $L P$ can be analyzed in terms of the absence of a power on the part of $A$ vis-à-vis $B$ to change $L P$.

Fifth, Hohfeld points out that lawyers tend to use the term 'right' in a number of different ways, sometimes meaning 'claim', sometimes meaning 'liberty', sometimes meaning 'power', and sometimes meaning 'immunity,' and that the term 'right' is therefore ambiguous. However, Nigel Simmonds argues that Hohfeld thought of claims as claim-rights, of liberties as liberty-rights, and so on, and as having peremptory force, and that this means that his analysis differs in an interesting way both from the above-mentioned view that legal rights are internally complex and have peremptory force and from the view espoused by Joseph Raz and Neil MacCormick, according to which legal rights are internally complex but lack peremptory force. ${ }^{30}$

\section{The Will-Theory and the Interest-Theory ${ }^{31}$}

Most viable analyses of the concept of a legal right fall into one of two categories: the category of will-theories (or choice-theories), or the category of interest-theories (or benefit theories). ${ }^{32}$ In a nutshell, whereas the former type of theory emphasizes the right-holder's legally recognized will (or choice) and in so doing aims to protect the right-holder's freedom or autonomy, the latter type seizes on the right-holder's legally protected interest, thus aiming to protect the right-holder's welfare, more generally. In what follows, I shall discuss Hart's analysis as an example of the will-theory and Neil MacCormick's analysis as an example of the interest-theory. I shall begin with the former type of theory and proceed to consider the latter.

30 Simmonds, Central Issues (n 12) 270.

31 Parts of the texts in this section can be found, more or less verbatim, in Torben Spaak, The Concept of Legal Competence: An Essay in Conceptual Analysis (Transl. Robert Carroll, Dartmouth, 1994) 146-50.

32 An interesting exception is Alf Ross's syntax-based account of the concept of a legal right, in Ross, 'Tü-Tü' (n 16). Ross's account is not an analysis in the strict, philosophical sense, because it does not aim to analyze the semantic import of the concept of a legal right, but aims instead to identify a syntactic function that the concept fulfills, namely, that of connecting a disjunction of legal grounds and a conjunction of legal consequences. I discuss Ross’s account in Spaak, 'Alf Ross' (n 16). 


\section{The Will-Theory: Hart's Account}

H. L. A. Hart is probably the writer who has done most in our time to develop the will-theory, ${ }^{33}$ which has also been defended by Bernhard Windscheid, ${ }^{34}$ Hans Kelsen, ${ }^{35}$ and, more recently, by Carl Wellman, ${ }^{36}$ Wayne Sumner, ${ }^{37}$ Nigel Simmonds, ${ }^{38}$ and Hillel Steiner. ${ }^{39}$ Hart primarily examines rights of private law, distinguishing between three main types of rights: claim-rights, liberty-rights, and power-rights. These three have in common, he says, that the right-holder has a legally respected choice. ${ }^{40}$ Thus, he stresses the agent's choice, emphasizing that — in the case of claim-rights - the important thing is that the legal order has given the agent the possibility to decide for himself whether or not the counter-party's duty must be fulfilled. Hart writes:

The idea is that of one individual being given by the law exclusive control, more or less extensive, over another person's duty so that in the area of conduct covered by that duty the individual who has the right is a small-scale sovereign to whom the duty is owed. ${ }^{41}$

The fullest measure of control comprises, Hart continues, three distinguishable elements, namely, (i) the power to waive or extinguish the corresponding duty, (ii) the power to enforce the duty by taking legal action, and (iii) the power to waive the other person's duty to pay compensation if she does not fulfill her duty. ${ }^{42}$ Although his extensive control is mostly at hand in private law, Hart points out that we have good reason to speak of rights outside of private law as well, not least in social law, where those who meet certain requirements are entitled to certain benefits. For, he observes, ${ }^{43}$ in these cases the persons in question have a certain, though not full, control over the duty of the public servants to supply the relevant benefits.

As we have seen, on Hohfeld's analysis, Smith's (naked) liberty vis-à-vis Jones to do (or not do) $X$, say, mow his (Smith's) lawn, corresponds to Jones's no-claim that Smith do not mow his lawn, not to a legal duty on Jones's part not to interfere when Smith is exercising his liberty. To explain how it can be that

33 Hart, 'Legal Rights' (n 13).

34 Bernhard Windscheid, Lehrbuch des Pandektenrechts. Erster Band (9th edn, arranged by Dr. TH. Kipp, Rütten \& Loening, 1906) 56.

35 Hans Kelsen, General Theory of Law and State (Transl. Anders Wedberg, The Lawbook Exchange, 1999) 79-83. (Originally published by Harvard University Press 1945.)

36 Wellman, 'Legal Rights' (n 20); Carl Wellman, A Theory of Rights. Persons under Laws, Institutions, and Morals (Rowman \& Allanheld, 1985).

37 Sumner, Moral Foundation (n 10).

38 N. E. Simmonds, 'Rights at the Cutting Edge' in Kramer, Simmonds, and Steiner (eds), A Debate over Rights (n 20) 113-232.

39 Steiner, 'Working Rights' (n 20). I discuss the views of Windscheid and Kelsen in Spaak, Competence (n 31) 144-6.

40 Hart, 'Legal Rights' (n 13) 197.

41 ibid. 191-2.

42 ibid. 192.

43 ibid. 194. 
Smith's liberty to mow his lawn does not entail a duty on the part of others not to disturb Smith's exercise of this liberty, even though a quick look at the content of contemporary law may suggest that liberties do entail such a duty, Hart introduced the useful concept of a protective perimeter and pointed out that the holder of a legal liberty can exercise his liberty behind this protective perimeter:

... where a man is left free by the law to do or not do some particular action, the exercise of this liberty will always be protected by the law to some extent, even if there is no strictly correlative obligation upon others not to interfere with it. This is so because at least the cruder forms of interference, such as those involving physical assault or trespass, will be criminal or civil offences or both, and the duties or obligations not to engage in such modes of interference constitute a protective perimeter behind which liberties exist and may be exercised. ${ }^{44}$

Note that it is a difficult matter to determine precisely where the line is to be drawn between legitimate and illegitimate interference with the right-holder's exercise of his liberty, and that this is so whether we think of the duty not to interfere as included in the relevant right or as an independent duty that constitutes a protective perimeter. For example, if I have a legal liberty-right to start a business, it does not follow that my neighbor has a legal duty not to interfere by starting a competing business, though it does follow that he has a duty not to interfere by blocking the entrance to my office or harassing my customers. But why should we draw the line precisely here?

In any case, Hart admits that he finds it difficult to account for a fourth type of (alleged) rights, namely, constitutional immunity-rights, because here the right-holder cannot control the counter-party's disability. For example, Swedish citizens have no control - except, of course, in a general election - over the legal disability, according to the Swedish Constitution, on the part of the legislature to impose capital punishment even for serious crimes, or to extradite Swedish citizens. But, Hart points out, this type of right does not belong to the core of law or, as he puts it, "[to] the level of the lawyer concerned with the ordinary working of the law." ${ }^{45}$ To this we should add, however, that there are immunity-rights on the level of private law, because in private law the right-holder can typically control the counter-party's disability.

\section{Wellman's Account}

It is worth noting that Carl Wellman defends a version of the will-theory that is rather similar to Hart's version, and that in doing so he draws explicitly on Hohfeld's analysis. ${ }^{46}$ Having made a distinction between the core Hohfeld element of a right and the associated Hohfeld elements, Wellman argues that the core element defines the right, whereas the associated elements confer on the right-holder autonomy in the sense of freedom and control over the core, and that the function of legal rights is precisely to give the right-holder autonomy as regards the object of the right. ${ }^{47}$ For example, if we think of the core of the right

\footnotetext{
44 ibid. 179-80.

45 ibid. 201. Hart does not, however, elaborate on this.

46 Wellman, 'Legal Rights' (n 20).

47 ibid. 219.
} 
to free speech as a liberty to speak out, we can say that the set of associated elements, which includes claims, liberties, powers, and immunities, confers autonomy on the right-holder over the liberty of speaking out. For the rightholder will have a liberty not only to speak out, but also not to speak out, ${ }^{48}$ a claim that no one interferes with his action of speaking out, a power over the counter-party's no-claim that he not speak out, and an immunity in relation to other people, including the police, who may wish to take away his liberty to speak out. And, as we have just seen, even if the liberty-right to speak out did not entail a duty for any counter-party not to interfere, the right-holder would normally enjoy the benefits of a protective perimeter consisting of independent legal duties. As Wellman sees it, a legal right is therefore best thought of as a system of autonomy: "The various legal claims, liberties, powers, immunities and duties that make up a legal right function together to allocate some specific autonomy to its possessor. Accordingly, a legal right is best thought of as a system of legal autonomy." 49 I find Wellman's characterization of a legal right as a system of autonomy enlightening, though I do not think there is much difference in substance between Wellman's and Hart's analyses.

\section{The Interest-Theory}

Towards the end of the nineteenth century, and in opposition to the dominant view at the time, that is, Bernhard Windscheid's will-theory, Rudolph von Jhering presented an analysis of the concept of a legal right, according to which a legal right consists of a substantive element, namely, an interest, and a formal element, a protection of this interest, and he therefore characterized a right as a legally protected interest:

There are two components that constitute the concept of right: one material, wherein the practical purpose of it lies, namely, usefulness, advantage and profit, which is to be ensured by the right; and one formal, which relates to this purpose only as a means, namely legal protection, petition. The former is the core, the latter is the shell, of right. That by itself only establishes an actual state of use or enjoyment (factual interest), which can be canceled at any time without further consequences by anyone who is factually able to do so. This state loses its character of coincidence and frailty only when the law takes it under its protection, and enjoyment, or the prospect thereof, becomes thereby secured: a right. The concept of right is founded on the legal certainty of enjoyment; rights are legally protected interests. ${ }^{50}$

48 On Hohfeld's analysis, if the right-holder did not have a liberty not to speak out, he would have a duty to speak out; and this would take away his autonomy over the counter-party's no-claim that he does not speak out. Strictly speaking, and for the same reason, the rightholder also needs a liberty to exercise his power and his immunity and a liberty not to exercise them.

49 Wellman, ,'Legal Rights’ (n 20) 219.

50 Rudolph von Jhering, Geist des römischen Rechts auf den verschiedenen Stufen seiner Entwicklung. 3 Teil. (3rd ed., Leipzig, 1877) 327-8. Translated into English by Robert Carroll, who wishes to thank Christoph Bezemek for offering valuable help. The German original reads as follows: "Zwei Momente sind es, die den Begriff des Rechts constituiren, ein substantielles, in dem der praktische Zweck desselben liegt, nämlich der Nutzen, Vortheil, Gewinn, der durch das Recht gewährleistet werden soll, und ein formales, welches sich zu jenem Zweck bloß als Mittel verhält, nämlich der Rechtsschutz, die Klage. Ersteres ist der 
What is new in von Jhering's definition, then, is the idea that having a right is having a legally protected interest, and that the right-holder's ability to take legal action is only a means to the end of having the object of the right in peace. In later years, David Lyons, ${ }^{51}$ Neil MacCormick, ${ }^{52}$ Joseph Raz, ${ }^{53}$ and Matthew Kramer $^{54}$ have presented similar lines of thought. In what follows, I shall focus on MacCormick's account.

\section{MacCormick's Account}

MacCormick, who is focusing on a child's right to be treated by his or her parents or guardians in a certain way, maintains that a person, $A$, has a legal right to $X$ if, and only if, (i) in conferring a right on $A$ to $X$, the law is thought of as advancing the interests of $A$ (and on the members of the class to which $A$ belongs), on the assumption that $X$ is, in all normal circumstances, good for $A$, and (ii) the law has the effect of making it legally wrongful to withhold $X$ from A. ${ }^{55}$ On MacCormick's analysis, then, such a right of a child to a certain treatment is a legally protected interest, because (a) the treatment is typically good for the child, and because (b) it would be legally wrongful to withhold the treatment from the child.

MacCormick does not, however, analyze the concept of a legal right in terms of Hohfeld elements. For he rejects the view that rights presuppose the existence of duties, arguing instead that the existence of a right is often a reason to impose a duty on someone. He offers as an example of a right that does not presuppose the existence of any duty, but is rather a reason to impose a duty on some people, a right conferred on Scottish children by the Scottish Succession Act of 1964, section 2(1)(a), which reads as follows: "Subject to the following provisions of this Part of this Act, (a) where an intestate is survived by children, they shall have a right to the whole of the intestate estate.” As interpreted by MacCormick, this section provides that a child whose parents have died, has, first, a legal right to a share of the estate, and, secondly, a legal right to be appointed executor, where neither right presupposes the existence of a corresponding duty. As MacCormick sees it, this is proof that there are legal rights that do not presuppose

Kern, letzteres die schützende Schale des Rechts. Jenes für sich allein begründet lediglich einen thatsächlichen Zustand des Nutzens oder Genusses (faktisches Interesse), der jeder Zeit ohne weitere Folgen von Jedem, der dazu thatsächlich in der Lage ist, aufgehoben werden kann. Den Charakter der Zufälligkeit, Hinfälligkeit verliert dieser Zustand erst dadurch, daß das Gesetz ihn unter seinen Schutz nimmt, der Genuß oder die Aussicht auf denselben wird dadurch ein gesicherter: ein Recht. Der Begriff des Rechts beruht auf der rechtlichen Sicherheit des Genusses, Rechte sind rechtlich geschützte Interessen.“

51 David Lyons, 'Rights, Claimants, and Beneficiaries' (1969) 6 American Philosophical Quarterly 173-185.

52 Neil MacCormick, 'Children’s Rights: A Test-Case for Theories of Right' (1976) 62 Archiv für Rechts- und Sozialphilosophie 305-317; Neil MacCormick, 'Rights in Legislation' in P.M.S. Hacker and J. Raz (eds), Law, Morality, and Society. Essays in Honour of H. L. A. Hart (Clarendon Press, 1977) 189-209.

53 Joseph Raz, The Morality of Freedom (Clarendon Press, 1986) 165-92.

54 Kramer, 'Rights Without Trimmings’ (n 20).

55 MacCormick, ‘Children’s Rights’ (n 52) 311. 
the existence of legal duties, but are instead reasons to impose duties on someone:

By virtue of that [the relevant piece of legislation], whenever any person domiciled in Scotland dies having left no valid will, there automatically vests in his children (if any) a right to the whole of that part of his estate statutorily denominated 'the intestate estate'. At the moment of its vesting, the right is not a 'real right' involving ownership of the estate or any part of it. It is a right to receive, in due course, a proportionate share in the assets remaining in the executor's hands after satisfaction of prior claims. But note that at the moment at which the right vests there is as yet no executor to bear the correlative duty. The executor must be judicially confirmed or appointed in due course, and what is more, if the estate is solvent those who have beneficial rights in it are normally preferred to other parties in the appointment of an executor dative. So any child who is of sufficient age may, in virtue of the right conferred by the Act, have a resultant if defeasible right to be appointed as executor. His appointment as such will in turn result in his acquiring the duties of executor, including the duty of distributing the intestate estate to those (including himself) who have the right thereto in virtue of section $2 .{ }^{56}$

I do not find MacCormick's argumentation convincing, however. First, the fact that the law-maker uses the term 'right' in the relevant piece of legislation (which is a first-order legal statement) is not decisive. For one thing, the lawmaker will typically have no clear view of what a legal right is, but will use the term 'right' when it is rhetorically convenient. And even if the law-maker did have a clear view of what a right is, it does not follow that legal scholars who are analyzing, or explicating, the concept of a legal right, are in any way bound by what the law-maker says or intends about that concept.

Secondly, when MacCormick claims that the right is temporally (and therefore conceptually) prior to the corresponding duty because there is as yet no executor to bear the duty when the right vests, he is overlooking the distinction between the office of the executor and the person who is the holder of the office at a particular point in time. ${ }^{57}$ Although no holder of the office has yet been appointed, there is still the office of the executor, and we may say that it is this office that is the bearer of the corresponding legal duty. Thus, this (primary) right is not an example of a right that is prior to the relevant duty and a reason to impose a duty.

Thirdly, it is not clear why the fact that those who have beneficial rights in the estate are "normally preferred" as executors should be thought to amount, or give rise, to a legal right on their part to be appointed executor, and MacCormick does not explain why this should be so. Thus, this (secondary) right, too, is not an example of a right that is prior to the relevant duty and a reason to impose a duty, for it does not seem to be a right at all.

Fourthly, MacCormick appears to undermine the very interest-theory he is defending when he maintains both that rights are (i) legally protected interests and (ii) temporally and therefore conceptually independent of the relevant legal duties. For if, as MacCormick proposes, the concept of legal protection is included in the analysis (in the analysans) of the concept of a legal right, then the right itself cannot, on pain on circularity, exist independently of this

\footnotetext{
56 ibid. 312.

57 On this, see Simmonds, Central Issues (n 12) 286.
} 
protection, and this in turn means that the right cannot be a reason to impose the duty that would constitute this very protection. The natural conclusion is that MacCormick's version of the interest-theory of rights is incoherent.

\section{The Will-Theory and the Interest-Theory: a Hohfeldian Approach}

If we thus reject the view espoused by MacCormick and Raz that a right is a reason to impose a duty (or a no-claim, liability, or disability, or a combination of such elements) on the counter-party and think instead of a legal right as a complex of Hohfeld elements, one of which constitutes the core of the right and the rest of which are the associated elements, we may say that under the willtheory, the function of the associated elements is to confer control (Hart), or autonomy (Wellman), on the right-holder over the counter-party's duty, noclaim, liability, or disability, and that under the interest-theory, the function of these elements is to protect the right-holder's interest by regulating the counterparty's duty, no-claim, liability, or disability. We see, then, that will-theories seize rather narrowly on what the legal right-holder can do legally qua rightholder, whereas interest-theories seize on general reasons to legally protect a person's interest. As Wayne Sumner puts it,

[t]he interest conception treats rights as devices for promoting individual welfare. Thus the dominating image here is that of the right-holder as the passive beneficiary of a network of protective and supportive duties shared by others, from which it follows that a being can be a right-holder only if it possesses interests. On the other hand, the choice conception treats rights as devices for promoting freedom or autonomy. Thus the dominating image here is of the right-holder as the active manager of a network of normative relations connecting her to others, from which it follows that a being can be a right-holder only if it possesses these managerial abilities. ${ }^{58}$

Although it is not obvious that aims that are so different must yield incompatible analyses, the competing analyses that have so far been proffered have differed quite a bit not only as regards the intension (meaning) of rights statements, but also as regards the extension (the entities that fall into the relevant category) of such statements. Generally speaking, the interest-theory tends to generate more rights than the will-theory, since there is a larger class of creatures who are capable of having interests than there are creatures who are capable of having and exercising autonomy. We will return to this question in our discussion of the pros and cons of the respective type of analysis below (in Section 9).

On a Hohfeldian approach, we may thus say that, under the will-theory, $A$ has a claim-right vis-à-vis $B$ that $B$ do (or not do) $X$ if, and only if, the function of the associated elements is to confer autonomy on $A$ over $B$ 's duty, whereas under the interest-theory, $A$ has a claim-right vis-à-vis $B$ that $B$ do (or not do) $X$ if, and only if, the function of the associated elements is to protect the right-holder's interest by regulating $B$ 's duty; that under the will-theory, $A$ has a liberty-right vis-à-vis $B$ to do (or not do) $X$ ) if, and only if, the function of the associated

58 Sumner, Moral Foundation (n 10) 47. 
elements is to confer autonomy on $A$ over $B$ 's no-claim that $A$ not do (or do) $X$, whereas under the interest-theory, $A$ has a liberty-right vis-à-vis $B$ to do (or not do) $X$ if, and only if, the function of the associated elements is to protect $A$ 's interest by regulating $B$ 's no-claim; that under the will-theory, $A$ has a powerright vis-à-vis $B$ to change a legal position, $L P$, if, and only if, the function of the associated elements is to confer autonomy on $A$ over $B$ 's liability vis-à-vis $A$ to have $L P$ changed by $A$, whereas under the interest-theory, $A$ has a power-right vis-à-vis $B$ to change $L P$ if, and only if, the function of the associated elements is to protect $A$ 's interest by regulating $B$ 's liability; and that under the will-theory, $A$ has an immunity-right vis-à-vis $B$ as regards $B$ 's changing $L P$ if, and only if, the function of the associated elements is to confer autonomy on $A$ over $B$ 's disability vis-à-vis $A$ to change $L P$, whereas under the interest-theory, $A$ has an immunity-right vis-à-vis $B$ as regards $B$ 's changing $L P$ if, and only if, the function of the associated elements is to protect $A$ 's interest by regulating $B$ 's disability.

In light of the said, one may wonder just how big the difference is between having freedom and control over the counter-party's duty, no-claim, liability, or disability, on the one hand, and having one's interest protected by the regulation of the counter-party's duty, no-claim, liability, or disability, on the other. One may, in particular, wonder whether having freedom and control over the counterparty's duty, etc., is not really a special case of having one's interest protected by the regulation of the counter-party's duty, etc., and therefore whether the willtheory may not simply be a special case of the interest-theory. However, even if this is so, the fact remains that the theories differ in important respects, since the law may protect a person's interest in other ways than by conferring on him autonomy over the counter-party's duty, no-claim, etc., and we may therefore continue to speak of the two competing analyses of the concept of a legal right precisely as two competing analyses.

\section{The Will-Theory and the Interest-Theory: Pros and Cons}

My own view is that the will-theory offers a better analysis of the concept of a legal right than does the interest-theory. The main advantage of the will-theory, as I see it, is that it identifies an important property of right-holders, namely, that they are, as Hart puts it, small-scale sovereigns, in the sense that they have freedom and control over the counter-party's duty, no-claim, liability, or disability. The main disadvantage of the will-theory is that a person who does not have freedom and control over the counter-party's duty, etc., does not and cannot have a right, even though we sometimes may wish to say precisely that he does have a right. A case in point would be constitutional rights. In my view, the main advantage of the interest-theory is simply that it avoids the disadvantage of the will-theory just mentioned, since it allows us to say precisely that a person who does not have freedom and control over the counter-party's duty, etc., can nevertheless have a right, provided, of course, that the relevant duty, etc. constitutes a legal protection of her interest. As has been noted by Kelsen and Hart and many others, ${ }^{59}$ the main disadvantage of the interest-theory is that being a right-holder, on this analysis, is not a very interesting property,

59 Kelsen, General Theory (n 35) 77-8; Hart, 'Legal Rights’ (n 13) 190. 
because rights turn out to be nothing more than reflexes of the counter-party's duty, etc. That is to say, you can describe the alleged right-holder's legal position exhaustively in terms of legal duties (no-claims, liabilities, or disabilities), which are conceptually simpler and more basic than rights, and this means that speaking of rights in such cases is redundant.

The central objection to the will-theory, then, is that it cannot, at least not without difficulty, account for the fact, assuming it is a fact, that a person may be a right-holder, even though he does not have freedom and control over the counter-party's duty, etc. MacCormick, for example, maintains that the willtheory is inadequate, because it cannot account for the fact that children have rights, both legal and moral. ${ }^{60}$ In doing so, he not only assumes (without discussion) that children do have rights, but he also rejects the usual defense on the part of will-theorists, namely, that children can have legal rights, if and to the extent that there is a legal representative, who can exercise the child's rights on his behalf. For, MacCormick points out, it is implausible to think of a parent as acting on behalf of the child in matters concerning the child's legal right to care and nurture vis-à-vis that very parent. ${ }^{61}$

I am not convinced by MacCormick's objection, however. I agree, of course, that a parent could hardly act as a legal representative of a child as regards the very same parent's duty to care for that child. I would, however, solve this problem by arguing either (i) that the child simply does not have a legal right to be cared for, while acknowledging, indeed insisting, that the parent has a legal duty to care for the child, or else (ii) that the child has a legal representative who can act on his or her behalf, namely, his or her parents, or, in the case MacCormick describes, a representative who is not identical with the child's parents.

I believe (i) is the better solution to the problem, because it is simpler and does not mean that we miss out on anything important. The pertinent question, as I see it, is this: What is the point of insisting that the child has a legal right to be cared for that corresponds, but does not add anything, to the legal duty of the parents to care for the child? MacCormick does not consider this question, but his way of presenting the problem suggests that he thinks that at bottom this is a moral problem, that it would be outrageous to withhold such a legal right from the child. I cannot, however, see that there is anything of a moral nature at stake here. For adding a legal right to care and nurture on the part of the child understood along the lines of the interest-theory analysis - to the existing legal duty on the part of the parents to provide such care and nurture simply would not amount to more or better legal protection for the child. Hence, I can see no good moral reason to insist that the child has such a legal right. The problem for interest-theorists, then, is that having rejected the will-theory, on the grounds that children cannot have legal rights understood along the lines of that theory, they go on to assert that children do have legal rights under the interest-theory, according to which the existence of a legal right does not add anything of significance to the already existing legal duty. This does not seem to be a solution to the perceived problem.

\footnotetext{
60 MacCormick, 'Children’s Rights' (n 52).

61 ibid. 307.
} 
William Edmundson raises an objection to the will-theory, which is similar to MacCormick's objection but is more explicitly moral. ${ }^{62}$ The problem, according to Edmundson, is that being protected by a (legal or moral) duty on the part of another person does not amount to the same degree of protection as having a (legal or moral) right, and that this is so because rights, but not duties, function as side-constraints on the pursuit of goals and can thus give the rightholder a unique protection. ${ }^{63}$

I am not convinced by Edmundson's line of reasoning, however. The idea is that the decision-maker could treat duties, but not rights, as something that goes into (what Edmundson refers to as) an aggregative decision procedure and thus runs the risk of being outweighed by weightier considerations, and that therefore rights amount to better protection than duties. I cannot, however, see that a legislature aiming to enact a statute that would, say, require employees to work at least a fifty-hour week, on the grounds that such a piece of legislation would maximize welfare (by maximizing the gross national product), would be more constrained if it had to take into account a moral claim-right to be cared for on the part of children against their parents than if it only had to take into account a moral duty on the part of parents to care for their children. ${ }^{64}$

To see where Edmundson goes wrong, we need to ask what, exactly, he has in mind when he speaks of rights. Given that, on the interest-theory analysis, a legal claim-right on the part of children to care and nurture is nothing but a reflex of a legal duty on the part of parents to care for their children, which is intended to protect the interest of children, how could such a right function as a sideconstraint when the duty in question cannot? Clearly, if rights are to function in a way that duties cannot function, they must differ from duties in sufficiently important ways, say, by being systems of autonomy (Wellman), or legally respected choices (Hart). I conclude that Edmundson's objection is selfdefeating, in the sense that it can be successful only if it includes precisely what Edmundson rejects, namely, a will-theory analysis of the concept of a right.

If will-theorists nevertheless wish to maintain that children can and do have legal rights, even though they do not have, and cannot have, freedom and control over the counter-party's duty, etc., they could argue (ii) that children can be right-holders, if and to the extent that they have a legal representative that does have the freedom and control necessary to be a right-holder. Leaving MacCormick's difficult case to one side for the moment, I would say that in most cases the child's parents can be such a legal representative, and, if there are no parents available, perhaps a grandfather or a grandmother could be a legal representative. Such a representative would, of course, be under a legal duty to act at all times in the best interest of the child - if he were not thus duty-bound, he simply would not be a legal representative. This natural solution to the problem is, however, not without its difficulties when it is applied to the case of animals, and I shall consider some of them below (in Section 9).

62 William A. Edmundson, An Introduction to Rights (Cambridge University Press, 2004) 128.

63 On rights as side-constraints, see Robert Nozick, Anarchy, State, and Utopia (Basic Books, 1974) 28-42.

64 I am thus assuming that if parents had to work a fifty-hour week, welfare would be maximized, though they would also have less time to care for their children. 
MacCormick also identifies another, more general difficulty with willtheories. ${ }^{65}$ He points out that an individual has a (legal as well as a moral) right not to be deprived of his freedom, and a (legal as well as a moral) right not to be grievously assaulted, despite lacking the power to waive the counter-party's corresponding (legal or moral) duty not to deprive him of his freedom or grievously assault him. But, he points out, it would be strange if an individual were to have the right not to be caused certain types of minor physical harm (because the individual can waive the relevant duty) but not the right not to be caused grievous bodily harm (because he can't waive the relevant duty). MacCormick concludes that rights are better seen as protected interests (or kinds of benefits).

I do not agree with MacCormick. On the will-theory analysis, as I see it, ascribing rights to a person is a matter of respect for the individual's autonomy, which assumes his general ability to think for himself and choose and act as he sees fit. From this standpoint, one could argue that $A$ 's lacking autonomy over $B$ 's duty not to grievously assault $A$ is a case of unwarranted paternalism, and that any difficulties the will-theory may have to account for the rights of the relevant type are caused by paternalistic - and therefore illegitimate - legislation. I do not agree with this line of argument, however. I believe there are cases where a person's legal power to waive and liberty to waive or not waive a legal duty not to grievously assault him could be mercilessly exploited by criminal organizations, or other ruthless individuals, that there are thus good moral reasons to protect to some extent even adults of sound mind against themselves, and that therefore the legal order should not recognize such freedom and control over the relevant duty. If we keep this in mind, I see no real problem in saying that a person may have the right not to be assaulted in a minor way, say, in the context of sports, but not a right not to be grievously assaulted. For in such cases, the legal order simply does not respect the individual's ability to think for himself and choose and act as he sees fit, and this is as it should be. We see, then, that this objection, too, is really a moral objection to the will-theory, because the objection is at bottom that it is morally wrong to hold that while a person may have a (legal or moral) right not to be assaulted in a minor way, she does not have a right to be grievously assaulted. But, as I see it, there is no moral problem here. For the person in question would not be better protected by the legal (or the moral) order if she had the relevant right.

One might also object to the will-theory, that it does not seem to have the resources to determine which Hohfeld elements are part of a given right and which are not. Consider, for example, the question of whether or not legal liberty-rights include a claim that the counter-party not interfere with the rightholder's exercise of his liberty. In my view, one might here invoke the function of legal rights under the will-theory and argue (i) that it depends on whether the existence of such a claim is necessary for the right-holder to have autonomy over the counter-party's no-claim. The problem with (i), however, is, first, that it seems that the right-holder can indeed have autonomy over the counter-party's duty even without such a claim, and, secondly, that the existence of such a claim does seem to be necessary, if the right-holder is to be able to exercise his liberty, as he sees fit, since in the absence of such a claim the counter-party might act

65 MacCormick, 'Rights in Legislation' (n 52). 
legally if he does interfere. One might therefore be tempted to argue instead (ii) that it depends on whether the existence of such a claim is necessary for the rightholder to be able to exercise his liberty. This might seem to be an improvement. The problem with (ii), however, is that it introduces a brand new consideration, namely, the right-holder's ability to exercise his liberty, whose logical relation to the above-mentioned consideration, the right-holder's autonomy, is left unclear, and this suggests that what we have here is an ad hoc solution to our problem. I do not, however, believe that this objection is fatal to the will-theory.

As regards the interest-theory, I have the following objection to MacCormick's version of the theory, in addition to the general objection to interest-theories, that being a right-holder under the interest-theory is not a very interesting property, since the right is nothing but a reflex of a conceptually prior duty. As the reader will recall (from Section 6), MacCormick argues that a child, $C$, has a claim-right against some adult person, $P$, to treatment $T$ if, and only if, (i) $T$ is normally good for $C$ and is therefore in $C$ 's interest, and (ii) the law makes it legally wrongful for $P$ to withhold $T$ from $C$, where legal wrongfulness constitutes legal protection. But while a violation of a legal duty can in a natural way be thought of as a legal wrong, so that a duty on the part of $P$ to give $T$ to $C$ can be thought of as legal protection of $C$ 's interest in getting $T$ from $P$, it is decidedly less natural to say that the interest of the holder of a legal liberty-right, power-right, or immunity-right can be protected by having the law make the counter-party”s “violation” of the relevant no-claim, liability, or disability a legal wrong.

Suppose that $A$ has a liberty-right vis-à-vis $B$ to spend the day at the beach, or a power-right vis-à-vis $B$ to accept $B$ 's offer to purchase $B$ 's first-edition copy of The Great Gatsby. What could it even mean to say that $B$ has violated B's noclaim vis-à-vis $A$ that $A$ not spend the day at the beach, or $B$ 's liability vis-à-vis $A$ to have $B$ 's legal position changed by A's acceptance of $B$ 's offer? One might be tempted to argue that $B$ could somehow violate a no-claim or a liability by refusing to accept it, by raising a claim or insisting on immunity. But this would be a mistake. For whereas one can violate a duty by simply refusing to act accordingly, one cannot violate a no-claim or a liability (or a disability) by acting in a certain way. For example, could Smith be accused of violating his legal immunity against extradition by voluntarily traveling to the country that wants him extradited, or his legal power to draw up a will by ignoring the formal requirements regarding witnesses? I think not. The natural conclusion is that $B$ cannot in any meaningful sense commit a legal wrong in these cases, and this in turn means that we cannot say in these cases that $A$ 's interest is legally protected in the sense that the law has made $B$ 's actions legally wrongful.

MacCormick could perhaps argue that regardless of what type of right is in question, the counter-party will always be under a legal duty not to interfere with the right-holder's exercise of his right, and that it is this duty that constitutes the legal protection of the right-holder's interest. However, there may or may not be such a duty, and even in cases where there is such a duty, it is not necessarily part of the relevant right, but may instead be a protective perimeter duty in Hart's sense, such as a criminal law duty or a tort duty.

I conclude that while MacCormick's attempt to analyze the crucial concept of legal protection by means of the concept of legal wrongfulness is successful in the case of legal claim-rights, the analysis cannot be extended to cover liberty- 
rights, power-rights, or immunity-rights. Hence, the scope of application of the theory is too restricted.

Finally, it is worth noting that it has been said that the interest-theory mistakenly attributes rights to third-party beneficiaries of a contract, who are thus assumed to have a legally protected interest, because the received view is that it is the contracting party who has the relevant legal right, and that this makes it clear that being such a beneficiary is not a sufficient condition for being a rightholder. ${ }^{66}$ Suppose that $A$ and $B$ enter into a contract, according to which $B$ is to care for $A$ 's old father, $F$, and $A$ is to pay $B$ a sum of money for her services. Although $F$ is in a natural sense one whose interest is legally protected by $B$ 's duty to care for $F$, it is $A$ who is commonly considered to be the right-holder. The objection to the interest-theory, then, is that it gives the wrong answer namely, $F$ - to the question of who is the holder of the relevant claim-right.

True, the interest-theorist could dig in his heels and insist that it is not $F$, but $A$, who is the intended beneficiary of $B$ 's duty to care for $F$, or, perhaps, that both $A$ and $F$ are such beneficiaries, and that therefore $A$ is the holder of the claimright, or that both $A$ and $F$ are holders of a claim-right. Thus, much seems to depend on what, exactly, it means to have one's interest protected by somebody else's duty to do (or not do) something. Note, though, that if both $A$ and $F$ were considered to be beneficiaries of $B$ 's duty to care for $F$, the interest-theory could plausibly be accused of generating too many rights. This seems to be an unavoidable consequence of adopting a liberal view of who counts as having a protected interest. ${ }^{67}$ Note also that critics of the interest-theory must not assume the correctness of the will-theory in their discussion of third-party beneficiaries. ${ }^{68}$ If one wishes to argue that the interest-theory is ill adapted to the law of contract, ${ }^{69}$ one must argue that the interest-theory attributes a legal right to a person who is - independently of the will-theory - not naturally considered to be a legal right-holder.

\section{Animals as Legal Right-Holders}

When considering the question of whether animals can be legal right-holders, we may allow ourselves to focus on claim-rights, such as a right not to be harmed or, more generally, a right to be treated well. The reason is that such rights seem to be the most interesting rights for animals. To see that this is so, let us briefly consider in turn the likely value for animals of legal liberty-rights, power-rights, immunity-rights, and claim-rights.

To my knowledge, animals are not considered to be legal subjects (Rechtssubjekte) in any existing legal order, that is, they are not considered to have legal capacity (Rechtsfähigkeit), in the sense that they can have legal rights or duties. ${ }^{70}$ The question here is whether they can have legal rights; that they

66 Hart, 'Legal Rights’ (n 13) 195-6; Steiner, 'Working Rights’ (n 20) 284-6.

67 On this, see Steiner 'Working Rights' (n 20) 284-6.

68 On this, see Kramer, 'Rights Without Trimmings' (n 20) 66-8.

69 Hart, 'Legal Rights’ (n 13) 195.

70 On this, see Spaak, Competence (n 31) 11-9. See also Hans Kelsen, Reine Rechtslehre ( $2^{\text {nd }}$ edn, Österreichische Staatsdruckerei, 1960) 150-5, 162-7. 
cannot have legal duties is obvious. However, if they cannot have legal duties, and if having a legal liberty to do $X$ is equivalent to not having a legal duty not to do $X$, having a legal liberty, or a legal liberty-right, to roam free, say, would be pointless for animals, and any claim that they do have legal liberties, or legal liberty-rights, would be misleading, albeit true in a loose and vacuous sense.

Thinking of animals as having legal powers, or legal power-rights, does not seem meaningful either. Just as animals cannot have legal duties in a meaningful way, they cannot have legal powers in a meaningful way; and the reason in both cases is that animals do not have the capacity either to understand their legal positions, if they had any, or to act accordingly. For example, having the legal power to consent to being raised for food, or to be experimented on, would not be meaningful for animals, because they could not understand and so could not exercise such a legal power; and even if they could, the law should not (as we have seen in Section 9) recognize consent to grievous assault, still less consent to being killed.

Similarly, to hold that animals can have immunities, or immunity-rights, would not be meaningful either, because the point of having a legal immunity is to be protected from having one's own legal position changed. What is of interest to animals is not their own legal positions, however, because they do not have any (unless, of course, they can have legal rights), but how they are treated, and this means that they have - in principle - an interest in the legal positions of humans. One might think that having a constitutional immunity-right would be useful for animals, if and insofar as it would make it impossible for the legislature to enact legislation permitting hunting and killing of animals, or to repeal existing legislation that confers a claim-right on animals to be treated well, etc. Such a purported constitutional immunity-right for animals would not be a right for animals, however, since (as we have seen) it would not (because it could not) change the legal position of animals - though it would, if it existed, change the legal position of humans, namely, by entailing a legal disability on the part of the legislature. We see, then, that such a disability on the part of humans would not correspond to an immunity on the part of animals.

I conclude that what is of interest to animals is not their own legal positions, because they do not have any, but how they are treated, and such treatment is precisely what would be the content of animal claim-rights against humans. If we thus focus on claim-rights, and if we adopt the interest-theory of rights, we can say that an animal is a holder of a legal claim-right to be treated well if, and only if, its interest in being treated well is protected by a legal duty on the part of humans to treat them well, and that animals are therefore in this minimal sense legal subjects. As we have seen, however, such a claim-right would be nothing more than a reflex of the relevant duty, and this means that having such a right - in addition to simply being protected by the relevant human duty - would not be useful to animals.

The fact, assuming it is a fact, that having a legal right to be treated well, conceived along the lines of the interest-theory would not be useful to animals, suggests that an explication of the concept of a legal right along the lines of the interest-theory would not be fruitful, if and to the extent that such a right concept would also be used in the field of animal law. As the reader will remember (from Section 3), the point of an explication of a legal concept is to mold (or construct) a concept that will be adequate in light of a given purpose, say, that of being useful in legal thinking in general; and the criteria of adequacy for such an 
explication are theoretical, not practical, still less moral, namely, (i) similarity to the original concept, (ii) precision, (iii), fruitfulness, and (iv) simplicity. However, while an explication of the concept of a legal right along the lines of the interest-theory might meet criteria (i), (ii), and (iv), it could hardly meet criterion (iii): fruitfulness. For a legal right, specifically, a legal claim-right, whose content adds nothing but a label to a person's or an animal's legal position that could be exhaustively described in terms of legal duties, could hardly yield insights either into ordinary (first-order) legal thinking, typically, legal problemsolving, or into (second-order) thinking about law, say, about the place of law in society, or the moral value of a legal order that comports with the principles of the Rechtsstaat.

I believe, as I have said, that the will-theory offers a better explication of the intuitive concept of a legal right than does the interest-theory, and it does this by developing the idea (mentioned in Section 4) that to have a legal right is to be legally protected by the imposition of normative constraints on other persons in such a way that one is typically able to decide, according to one's own lights, how one is to act (or not act), or how another person is to act (or not act), in a more interesting and fruitful way than does the interest-theory. As we have seen, to have a legal right, on this analysis, is to have legal autonomy, that is, freedom and control, over the counter-party's duty, no-claim, liability, or disability; and to be in such a position is of considerable value - both from an instrumental and from a human point of view - to the right-holder. ${ }^{71}$

William Edmundson raises, as we have seen (in Section 9), a moral objection to the will-theory, namely, that the existence of a duty on the part of the parents to care for a child is a poor substitute for the child's having a right against the parents to be cared for, because rights, but not duties, function as constraints in practical reasoning and can therefore protect children from adverse decisionmaking or legislation in a way that duties cannot do. Clearly, Edmundson's reasoning applies to the case of animals, too. However, as I have said, I do not think Edmundson is right. Given that, on the interest-theory analysis, a legal (or a moral) claim-right is nothing but the reflex of a legal (or a moral) duty, such a right could hardly function as a side-constraint when the duty in question cannot. The only good reason I can think of for wishing to be able to say that animals (or children) have legal (or moral) rights, on the interest-theory analysis, lies in the symbolic value of such claims. To assert this is simply to assert the obvious value of animals or children as creatures with a life and interests of their own, which must be taken into account. In this general and loose sense, we may well speak of trees and flowers, too, as having rights (which is not to suggest that, morally speaking, children, animals, trees, and flowers are all on the same level).

Returning to the will-theory, we have seen that one can have autonomy only if one can choose to exercise one's autonomy, say, by choosing to waive the counter-party's duty (in the case of claim-rights), insisting on its fulfillment by taking legal action, etc., and, if one has chosen to exercise one's autonomy, to act accordingly. Clearly, under the will-theory, since animals cannot exercise

\footnotetext{
${ }^{71}$ Even though a person may not in all cases be able to make full use of his or her legal autonomy, perhaps because of a lack of funds or knowledge or know-how (you have a liberty-right to travel to Australia, but you can't afford the plane ticket, or you have a liberty-right to buy shares on the stock market, but you do not understand what drives the stock-market), this does not detract from the general value of being legally autonomous.
} 
such autonomy, they cannot have legal rights. As Hart puts it, "[i]t is an incidental, though substantial merit of this approach [the will-theory] that it provides an intelligible explanation of the fact that animals, even though directly protected by the duties of the criminal law prohibiting cruelty to them, are not spoken or thought of as having rights." 72 To this we should probably add that today - about 50 years later - animals are indeed thought of and spoken of as having rights, at least in certain, not insignificant quarters, and that therefore this particular argument is no longer as persuasive as it once was.

Now if we wish to think of animals as right-holders along the lines of the willtheory, we need to consider the possibility that an animal can be represented by someone who can have and exercise autonomy on its behalf. For, one might argue, if the parents of a child can exercise the child's rights on its behalf, the legal owner of an animal should be able to exercise the rights of the animal on its behalf. I myself would be quite happy to exercise our cat Edward's rights on his behalf. As I understand it, a person is said to be the legal representative of a child if, and only if, he is (i) legally authorized (by statute, appointment, or contract) to be the child's representative and (ii) legally obligated to act in the best interest of the child; ${ }^{73}$ and the reasons why such a representative is thought to exercise the legal rights of the child and not his own legal rights are (iii) that the child will one day become an adult and will then herself be able to exercise the relevant rights, and (iv) that what the representative can legally do is precisely what the child could have done if she had been an adult. ${ }^{74}$

This way of looking at things is somewhat problematic, however. First, although (i) and (ii) seem unproblematic as regards the question of who, if anyone, is the legal representative, (ii) might seem problematic when the question is whether the child (or the animal) is really a right-holder. For one might be tempted to argue that a representative who is under a legal duty to exercise autonomy on behalf of the child over the counter-party's duty (or noclaim, liability, or disability) towards the child simply cannot have autonomy over the relevant duty, etc., since (as we have seen) a person who has a duty to do $X$ cannot also be at liberty not to do $X$; and if one is not at liberty to do $X$ and at liberty not to do $X$, one cannot have autonomy (freedom and control) over $X$. And if the representative does not have autonomy, the child cannot be a rightholder.

Such an objection would be misconceived, however. For the legal duty to exercise autonomy on behalf of a child is a general duty to exercise such autonomy, not a specific duty to do (or not do) something that might be involved in exercising autonomy, say, insisting on a person's paying back a loan to the child; and this means that we can coherently say that a representative can have a legal duty to exercise autonomy on behalf of a child, while also being at liberty, say, to insist or not insist on payment of a debt owed to the child, and that therefore the representative's authority will not be undermined by the duty in question.

Secondly, if the representative does have autonomy on behalf of the child, why is not the representative the holder of the right in question? The answer to

72 Hart, 'Legal Rights' (n 13) 193.

73 Kelsen, Reine Rechtslehre (n 70) 162-7.

74 Hart, 'Legal Rights' (n 13) 192-3 note 86. 
this question is to be found in conditions (iii)-(iv) above. However, although one may well discuss the adequacy of these conditions as applied to children, ${ }^{75}$ the main problem in this context is that the conditions do not apply to animals. For unlike children, animals will not grow up to be adult human beings who can have rights under the will-theory; and this means that we cannot say that the animal and not the representative is the right-holder because the former will one day become an adult human and will then itself be able to exercise the relevant rights. On this analysis, then, we cannot explain why the animal and not the representative is the right-holder.

In addition to these theoretical difficulties, there are practical difficulties with the idea that a legal representative can exercise the rights of animals. For one thing, while the owner of a domestic animal can in most cases act on its behalf, who should act on behalf of wild animals? One could, of course, imagine a situation in which there is an animal ombudsman, whose task it is to act as a legal representative for animals that do not have a representative. Such a situation seems rather distant, however, and may also be rather costly. Note, however, that while such practical difficulties are of considerable political interest, they are not relevant to the question of whether the explication is adequate in the sense of satisfying the four conditions.

I conclude that ascribing legal claim-rights to animals is (1A) pointless, on the interest-theory analysis, because being the holder of a legal claim-right amounts, on this analysis, to nothing more than having an interest that is legally protected by a human duty, and because duties are simpler and more basic than rights, and (2) incoherent, on the will-theory analysis, because it turns out to be very difficult to explain why animals and not their legal representatives are holders of the relevant rights. Let me also point out that there is a second conclusion implicit in my claim that having a legal right on the interest-analysis is pointless for animals, namely, (1B) that we can use legal means to protect and care for animals as efficiently when we conceive of animal law solely in terms of human legal duties as we can when we conceive of animal law partly in terms of legal animal rights. And, as far as I can see, this means that the answer to the moral question of how we are to treat animals simply does not depend on the question of whether we think of animals as having rights - moral or legal.

\section{Animal Law and Animal Welfare}

Conceptual questions are not, of course, the most important thing in the field of animal law, or in any other field of law. What is most important in the field of animal law is that the content of animal law is such that its enforcement is likely to improve the situation for animals, by making sure that animals are not harmed or killed in factory farms, scientific laboratories, or in other places. There is, however, a place for conceptual inquiries in this field, as in other legal fields. For such inquiries are conducive to clear legal thinking, and clear legal thinking is conducive not only to correct legal thinking, but also to efficiency, in the sense

75 The relevance of condition (iii) is not clear to me. Why, exactly, should the future agency of the child be relevant to the question of whether the child now has legal rights? Perhaps the answer is simply that there are pressing practical reasons to think of children as legal rightholders, especially as holders of property-rights. 
that it helps us focus on genuine problems and avoid distractions; and efficiency in turn tends to make the relevant activities - such as legal scholarship, judicial proceedings, and legislative work - less costly. Such considerations become even more persuasive, if we can achieve the same substantive results in our efforts to protect animals by focusing solely on human legal duties instead of partly on animal legal rights.

Animal protection does not come cheaply, however. Not only is it costly in financial terms, it will also be costly in human terms. For it seems a foregone conclusion that we will have to forego at least to some extent certain types of food and clothing, and perhaps also medical treatments, medicines, and more. As I see it, this is where the real problem lies. How much are we willing to give up in order to treat animals well, or at least decently? I myself believe we can and should do more than we are currently doing to root out the worst transgressions in factory farming, in animal experimentation, and in other places. ${ }^{76}$ We certainly do not need to give animals the right to be represented in legislative assemblies, or the right to vote, and I doubt that animals need to be property-owners. We should, however, cease to cause animals harm, as we are currently doing in factory farms and elsewhere.

76 On this general theme, see, e.g., Singer, Animal Liberation (n 1) chap. 3. 